\title{
Usage of UASB Reactor to Assess Feasibility of Treatment of Paper Mill Effluent
}

\author{
A. ARSHAD ${ }^{1 *}$, N. H. HASHIM ${ }^{2}$, A. Q. INTIKHAB ${ }^{1}$ AND N. GHAZALA ${ }^{3}$ \\ ${ }^{1}$ National University of Sciences and Technology (NUST), \\ Islamabad, (MCE Risalpur) Pakistan \\ ${ }^{2}$ Department of Civil and Environmental Engineering, UET Taxila, Pakistan \\ ${ }^{3}$ Fazia Degree College, Risalpur Cantt, Pakistan
}

\begin{abstract}
Upflow anaerobic sludge blanket (UASB) reactors R-I and R-II, each with an effective volume of 6.01 were used to study the treatability of actual effluent obtained from paper mills at a mesophilic temperature and neutral $\mathrm{pH}$. Methanol, as a source of an easily biodegradable substance along with activated carbon of effective size $1.5 \mathrm{~mm}-2.5 \mathrm{~mm}$ were added to the reactor R-I to a total depth of $12 \mathrm{~cm}$ to evaluate its efficiency. The $\mathrm{pH}$ of both the reactors were kept constant at neutral by adding an external buffer solution of $0.03 \mathrm{M} \mathrm{NaHCO}_{3}$ with the feed solution. It was observed that corresponding to an organic loading rate of $3.5 \mathrm{~kg}-\mathrm{COD} / \mathrm{m}^{3}$-day, the overall chemical oxygen demand (COD) removal efficiency of the reactors R-I and R-II were $88 \%$ and $64 \%$, respectively. The absorbable organic halides removal efficiency was observed to be $72 \%$ and $47 \%$ for reactor R-I and R-II, respectively. During the study it was however observed that, the treatability efficiency of reactor R-I was comparatively better but the amount of its biogas production was slightly lower than that of R-II. The average biogas production in reactors R-I and R-II during the course of study was observed as $0.33 \mathrm{l} / \mathrm{g}-\mathrm{COD}_{\text {removed }}$ and $0.42 \mathrm{l} / \mathrm{g}-\mathrm{COD}_{\text {removed }}$ respectively, with a mean methane composition of $58 \%-61 \%$ in both the reactors. Kinetic coefficients of $k, K_{s}, Y$ and $k_{d}$ were determined to be $0.7 \mathrm{~g}$-TOC/g-VSS.d, $0.30 \mathrm{~g}$-TOC/1, $0.26 \mathrm{~g}$-VSS/g-TOC and 0.02 day $^{-1}$ respectively, based on the results obtained from reactor R-I. The results of this study showed that the use of methanol and an activated carbon in a UASB reactor to anaerobically digest the paper mills effluent at a mesophilic temperature and a neutral $\mathrm{pH}$ reactor was quite a feasible and viable technique.
\end{abstract}

Key words: anaerobic digestion; activated carbon; methanol; COD; AOX; organic loading rate; design; parameters, pulping process; removal efficiency

Developing nations are highly subject to extensive environmental pollution, mainly due to the discharge of untreated industrial and domestic effluent. The paper mill industry is considered to be among the top-most pollution sources and releases a variety of toxic and hazardous wastes. It creates a massive threat to the environment by generating highly polluted effluent. The bleaching section of the mill discharges the most toxic type of effluent containing AOX (absorbable organic halides), which are produced as a result of the chemical combination of chlorine that comes from the bleaching section with the residual lignin of the pulping effluent (Ali et al. 2001; Savant et al.2005). AOX are highly hazardous because the majority of members of this family are bioaccumulative, persistent and carcinogenic in character. Dioxin, which is recognized to be the most deadly substance ever found on earth, also belongs to the same family of AOX (Arshad et al. 2009).

A variety of physical, chemical and biological techniques have been attempted to decrease the concentration of AOX in paper

\footnotetext{
* Corresponding author (e-mail: aliarshad08@yahoo.com)
} 
mill effluent. As the physical and chemical processes are extremely costly in terms of their operational and maintenance costings, biological treatment processes are generally chosen. Among the biological techniques, the anaerobic technologies are regarded as more feasible options, particularly for developing countries because of their minimal amount of energy and nutrient consumption (Bhatti et al. 1996). Moreover, the implementation of anaerobic technology has been demonstrated to be comparatively easy and cheaper while it can also be used for a variety of industrial and domestic waste treatments including the effluent of paper mills (Lettinga et al. 1980).

At present numerous anaerobic treatment systems are functioning effectively around the world for the treatment of paper mill effluents (Bajpai 2000). Although they are extremely acknowledged for their treatability performance (Schellinkhout 1993), only insufficient work has been reported so far regarding the use of UASB reactors to eliminate $\mathrm{AOX}$ from the effluent of paper mills using NSSC (neutral sulphide semi-chemical) pulping process, which is the common pulping technique being practiced in Pakistan (ETPI Pak-EPA 1999). It was earlier noticed that anaerobic technologies were able to reduce $40 \%-60 \%$ of the AOX concentration (Fitzsimons et al. 1990; Ferguson \& Dalentoft 1991). However, it has now been demonstrated that about $96 \%$ of the phenolic compounds can be removed at a hydraulic retention time (HRT) of 30 h (Anushuya \& Gupta 2008; Rajakumar \& Meenambul 2008; Mini Bajaj et al. 2009) but it's uneconomical to practically design a new UASB reactor merely on the basis of a longer retention time. Through its efficiency for the treatment of other kind of wastes like textile mill effluent, its COD removal has been reported to be more than $90 \%$ at a quite relatively reasonable HRT (Wijetunga et al. 2008)

It has been observed that the treatment efficiency of a UASB reactor could be enhanced by adding an additional source of an easily biodegradable substance to the reactor (Scholz et al. 1995; Bajaj et al. 2009). Adding methanol, the removal efficiency of the chlorophenolic wastes (members of the AOX family) in a UASB reactor had been observed to improve (Arshad \& Hashim 2008) and also using an activated carbon with the digested sludge in an UASB reactor increases its performance (Mahadevaswamy et al. 2004; Hiroshi \& Masasumi 2009; Arshad \& Hashim 2010). Therefore, this study was specifically designed to determine the optimum design parameters i.e. organic loading rate (OLR) and hydraulic retention time (HRT) for the treatment of paper mill effluent employing the NSSC pulping process under anaerobic conditions. The main objective of this study was to examine the removal efficiency of UASB in terms of COD and $A O X$ reduction using actual paper mill effluent in the presence of methanol and an activated carbon.

\section{MATERIAL AND METHODOLOGY}

\section{UASB Reactors Specification}

The UASB reactors (namely R-I and R-II) used were made of acryl resin material, each with an effective volume of 6.01 . Water jackets were provided around the reactors to maintain a constant mesophilic temperature. A mixing device (turbine shape, $3.81 \mathrm{~cm} \times 7.62 \mathrm{~cm}$ ) and a gas separator system were also provided in both the reactors (Arshad \& Hashim 2008). A systematic diagram of the UASB reactor is shown in the Figure 1.

The UASB reactor R-I was filled with granular activated carbon (effective size 1.5 $\mathrm{mm}-2.5 \mathrm{~mm}$ ) to the total depth of $12.7 \mathrm{~cm}$ (Arshad \& Hashim 2010).

\section{Wastewater Characteristics}

Actual wastewater sludge used in the study was obtained from the nearby local paper mill 


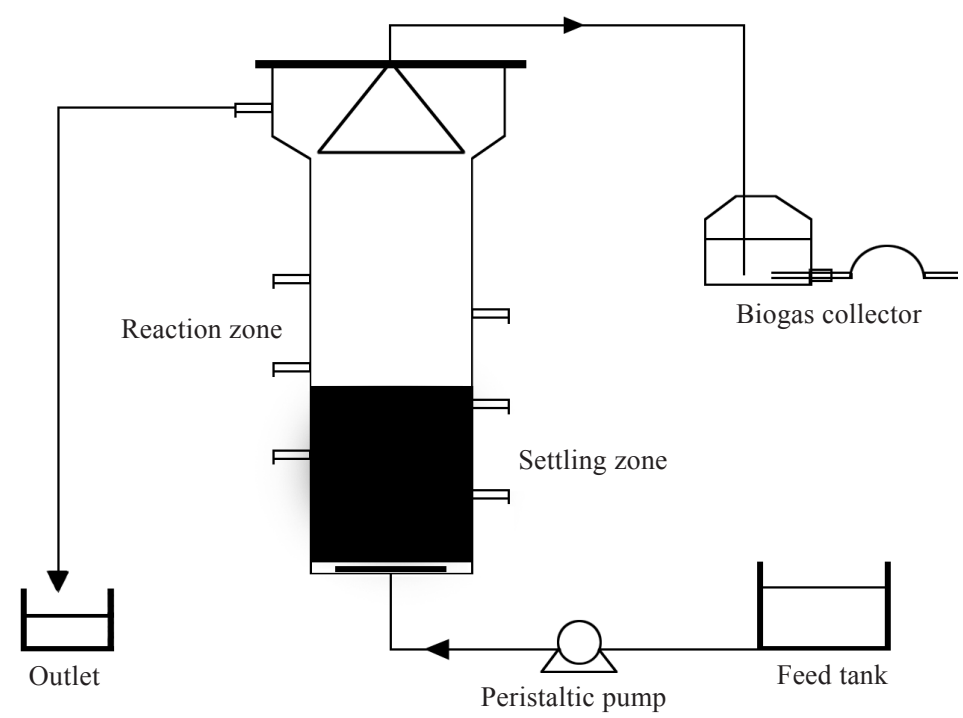

Figure 1. Systematic diagram of UASB reactor.

using NSSC pulping process. The wastewater characteristics data of the paper mills effluent is shown in the Table 1.

\section{Substrate and Nutrients}

Methanol was added to the feeding solution in reactor R-I to equalize its COD concentration to that of the actual effluent, by first diluting the same effluent with tap water. The ratio of methanol to actual effluent in the feeding solution to reactor R-I was kept around 1:5 (Arshad et al. 2010) during the course of study. For reactor R-II, the actual effluent without methanol was used as a feed solution.
Nitrogen and phosphorous were added to the feeding solutions of both the reactors, R-I and $\mathrm{R}-\mathrm{II}$ in the form of $\left(\mathrm{NH}_{4}\right) \mathrm{SO}_{4}$ and $\mathrm{KH}_{2} \mathrm{PO}_{4}$, respectively, in accordance with the $\mathrm{C}: \mathrm{N}: \mathrm{P}$ ratio of 300:1:0.1 (Athar et al. 2008). $\mathrm{MgSO}_{4} \cdot 7 \mathrm{H}_{2} \mathrm{O}$ was also added to both the reactors at the concentration of $0.1 \mathrm{~g} / 1$ (Bhatti et al. 1996).

\section{Seeded Sludge}

A digested sludge fully acclimatized with paper mill effluent in the laboratory for about three weeks was added to both the reactors for the start-up (Yoochatchaval et al. 2008). The concentration of MLSS and VSS of the seeded

Table 1. Wastewater characteristics of the paper mill effluent.

\begin{tabular}{l|c}
\hline Parameters & Concentration \\
\hline $\mathrm{Ph}$ & 8.2 \\
Colour (units) & 1650 \\
COD (mg/l) & 2984 \\
AOX (mg/l) & 22.08 \\
Total solids (mg/l) & 4562 \\
Total volatile solids (mg/l) & 1774 \\
Total dissolved solids (mg/l) & 2386 \\
Total suspended solids (mg/l) & 1094 \\
\hline
\end{tabular}


sludge were observed to be $62.28 \mathrm{~g} / \mathrm{l}$ and 54.55 $\mathrm{g} / \mathrm{l}$, respectively.

\section{Experimental Analysis}

The $\mathrm{pH}$, temperature, COD, AOX etc of the influent and effluent of the reactors were analyzed and recorded regularly twice a week. Total gas production was monitored using standard $\mathrm{NaCl}$ solution. All types of analysis were carried out using standard laboratory techniques (AWWA 2005).

\section{RESULT AND DISCUSSION}

\section{Operating Parameters}

Both the reactors were started up simultaneously and parallel according to the typical guidelines (Lettinga et al. 1984). As the $\mathrm{pH}$ and temperature were the two most important and principle operational parameters of anaerobic digestion, great care was therefore taken towards their control during the course of the study period. Neutral $\mathrm{pH}$ was considered to be the most suitable range for microbial activities during anaerobic digestion (Bhatti et al. 1996), thus the $\mathrm{pH}$ of both the reactors were maintained around neutral by adding an external buffer solution in the form of $0.03 \mathrm{M} \mathrm{NaHCO}_{3}$ to the feed solution after a few days of operation when a drastic drop of $\mathrm{pH}$ was observed in these reactors. The time course of $\mathrm{pH}$ during the study period of the reactors is shown in Figure 2.

The initial $\mathrm{pH}$ of both the reactors was slightly above neutral at the start of the study but later on a decreasing trend was observed after the second week. The $\mathrm{pH}$ of the reactors R-I and R-II suddenly dropped down to 5.51 and 5.02 , respectively. This normally happens under anaerobic conditions due to the accumulation of excess volatile fatty acids within the system during the start-up period but it can be controlled by adding an external buffer solution to the feed solution of the reactors. In this study, $0.03 \mathrm{M}$ $\mathrm{NaHCO}_{3}$ was used as the source of an external buffer to control the $\mathrm{pH}$ around neutral (Bhatti et al. 1996; Mtethiwa 2008). The average $\mathrm{pH}$ of both the reactors R-I and R-II after the addition of an external buffering solution was observed to be 7.10 and 7.22 , respectively during the course of study period, which also validated the effectiveness of using an external buffer solution (Arshad et al. 2010).

Similarly, for anaerobic digestion a mesophilic range of temperature was considered to be an optimum and suitable range (Henze et al. 1983) because at lower temperatures (Psychrophilic range) the microbial activity

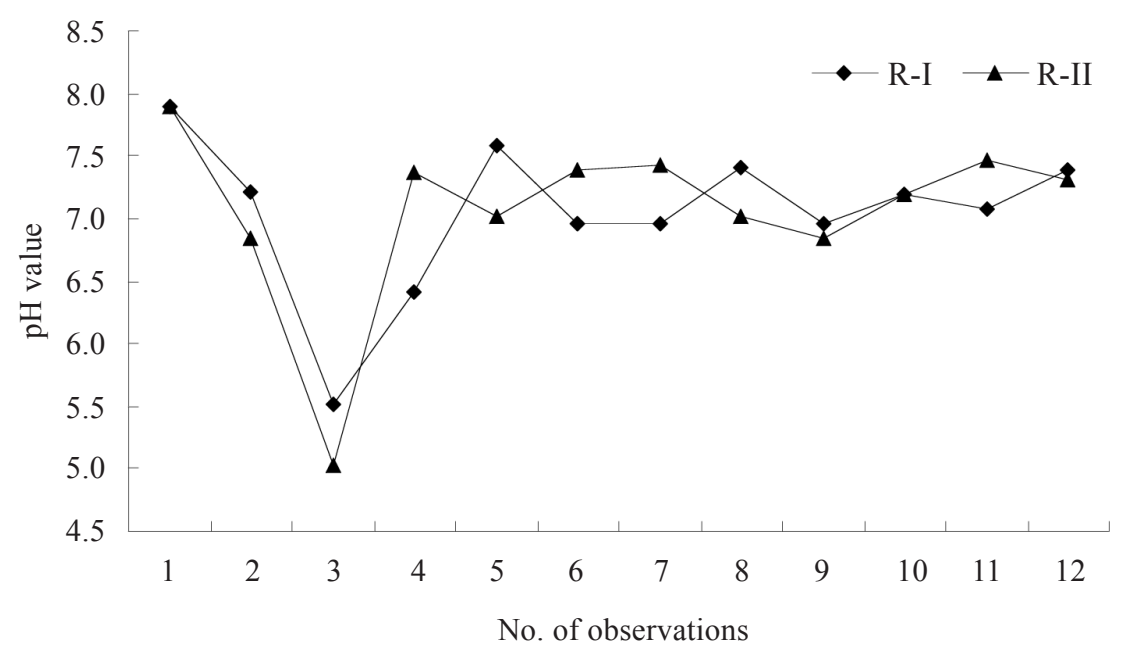

Figure 2. Time course of $\mathrm{pH}$ during the study period. 
becomes quite slow (Switzenbaum et al. 1980; Kennedy et al. 1982; Grin et al. 1985) while at higher temperatures (thermophilic range) a number of potential problems arise, e.g. high endogenous death rate (Henze et al. 1983; Buhr et al. 1977). Therefore, in this study the temperature of both the reactors was kept constant at $27^{\circ} \mathrm{C}-33^{\circ} \mathrm{C}$ by using external heating devices (water jackets).

Both the reactors R-I and R-II were started up simultaneously and in order to avoid organic shock to the reactors, the OLR was gradually increased starting from $0.2 \mathrm{~kg}-\mathrm{COD} / \mathrm{m}^{3}$-day to $5.5 \mathrm{~kg}-\mathrm{COD} / \mathrm{m}^{3}$-day and the hydraulic retention time (HRT) was slowly decreased from $78 \mathrm{~h}$ to $6 \mathrm{~h}$ during the course of the study period.

\section{Treatability Evaluation of the Reactors}

OLR and HRT are the important design parameters of wastewater treatment systems which determine the capital cost and establish their engineering and economic feasibility. During this study, the effects of OLR and HRT on the removal efficiency of COD and AOX concentrations in the reactors were observed thoroughly and the relevant data obtained during the course of the study period has been plotted as shown in Figures 3-6.
The data indicates that the treatment efficiency of the reactors R-I and R-II was greatly influenced by the OLR and HRT. The lower OLR and higher HRT seem to be in quite favourable conditions for achieving higher treatment performance under anaerobic conditions in both the reactors R-I and R-II in terms of COD and AOX removal, and viceversa. Such operational conditions of lower OLR and higher HRT make the system design uneconomical when applied to larger field scales. It was noticed that for every increase in OLR or decrease in the HRT, there was an abrupt decrease in the treatability performance of reactors R-I and R-II. This might be due to the sudden shock of a heavy organic load or the excessive accumulation of organic acids within the systems.

The data indicated that corresponding to optimum operating conditions, i.e. OLR of $3.5 \mathrm{~kg}-\mathrm{COD} / \mathrm{m}^{3}$-day and HRT of $22 \mathrm{~h}$, the overall COD removal in reactors R-I and R-II was $88 \%$ and $64 \%$, respectively. The AOX removal in reactors R-I and R-II corresponding to same operating conditions were noticed to be $72 \%$ and $47 \%$, respectively. Throughout the study, it was observed that the reactor R-I (with activated carbon) gave comparatively better treatment efficiency than the reactor R-II

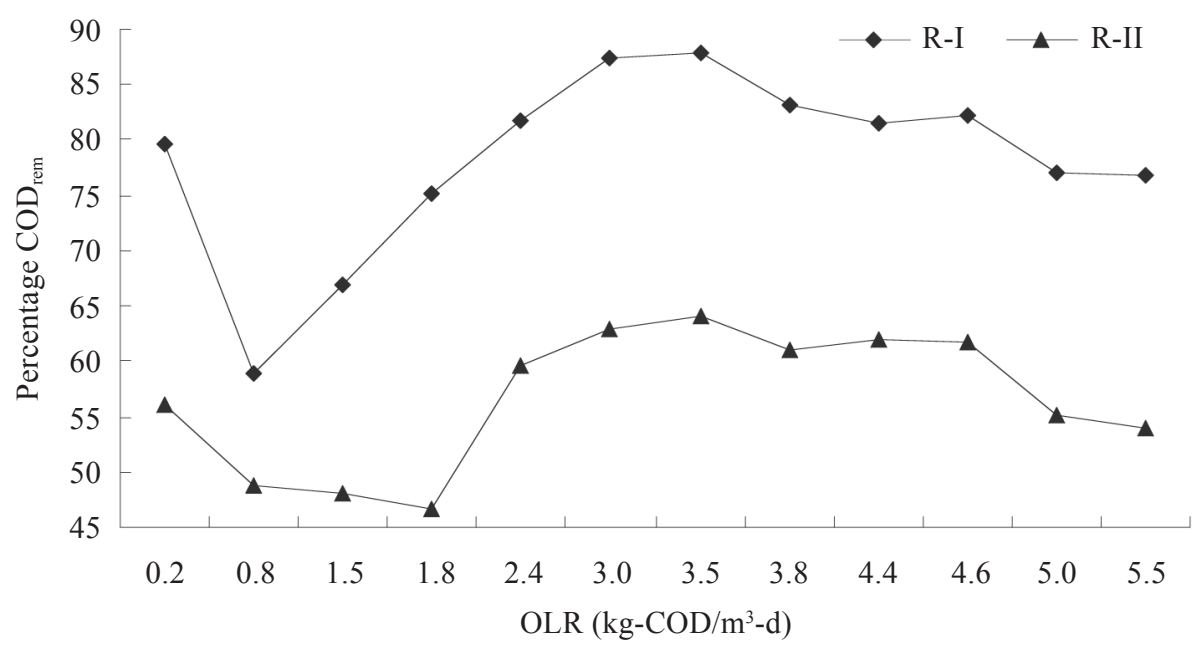

Figure 3. Effects of OLR on COD removal. 
(without activated carbon), which indicated that the addition of activated carbon to the UASB reactor enhanced its treatability performance.

The previous studies showed that anaerobic digestion, in combination with other treatment systems like aerobic, membrane filtration etc. is able to remove $40 \%-65 \%$ AOX (Lee et al. 1993; Hall et al. 1995; Francis et al. 1997; Tezel et al. 2001) but if it is used singlehandedly than only $42 \%-45 \%$ of AOX could be removed (Fitzsimons et al. 1990). Ferguson and Dalentoft (1991) reported 40\%-65\%
AOX removal while observing the treatability efficiency of the bleaching effluent of pulp and paper mills under anaerobic conditions. Comparison between COD and AOX removal efficiencies of the UASB reactors based on similar studies is mentioned in the Table 2. The present study seemed to be more reliable and gave better treatment efficiency of COD and AOX. This was because the new strategy was modified to work under anaerobic conditions in an UASB reactor where methanol as the source of an easily biodegradable substance was added to the feeding solution and also the usage of

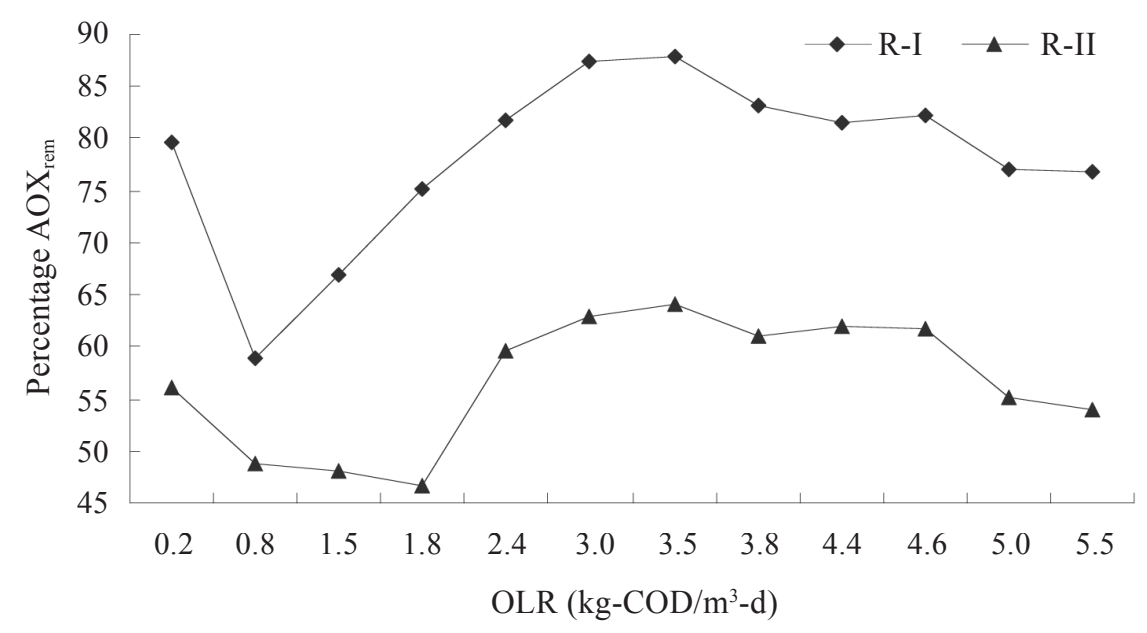

Figure 4. Effects of OLR on AOX removal.

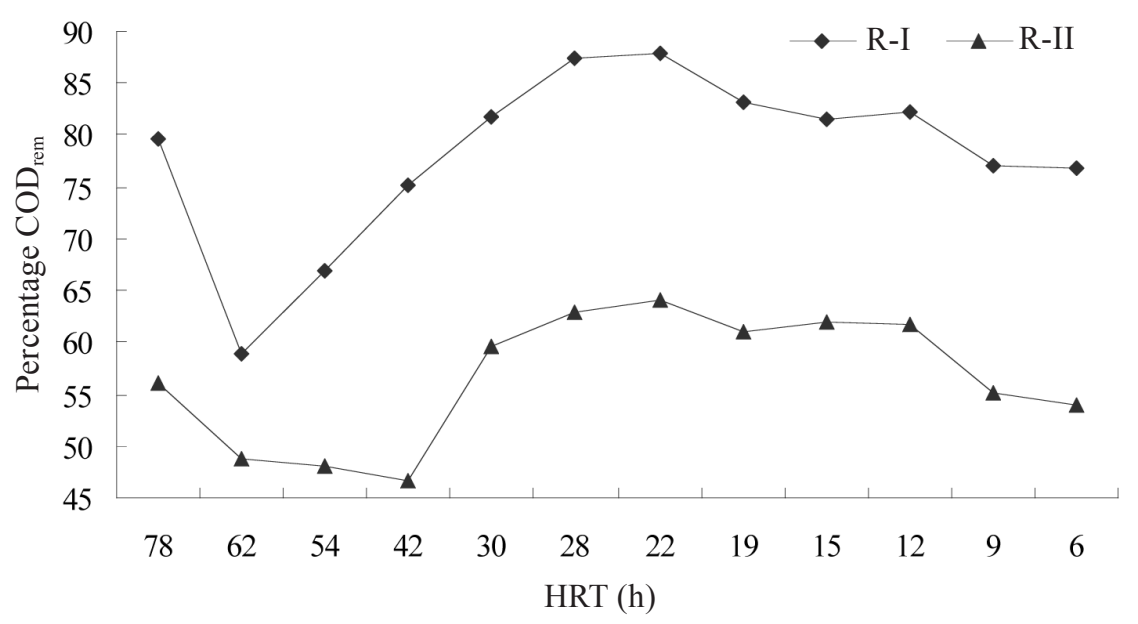

Figure 5. Effects of HRT on COD removal. 
activated carbon with the digested sludge. The Figures 4-6 provide practical design aid for the UASB reactor to treat paper mill effluent employing the NSSC pulping process.

\section{Production of Biogas}

Initially small gas bubbles were observed during the starting period. Appropriate collection of the biogas was done at the end of second week. The gas collection system consisting of saturated $\mathrm{NaCl}$ solution was installed in the reactors R-I and R-II. The data obtained pertaining to the biogas generated during the course of the study period is illustrated in Figure 7.

It was observed that the two design parameters i.e. OLR and HRT had important roles on the amount of biogas production under normal conditions of $\mathrm{pH}$ and temperature. The amount of biogas generated is directly related to the amount of feeding solution in the reactor, and the HRT plays a significant role in controlling the rate of biogas production. It was observed that there was a significant reduction in the amount of biogas production for both the

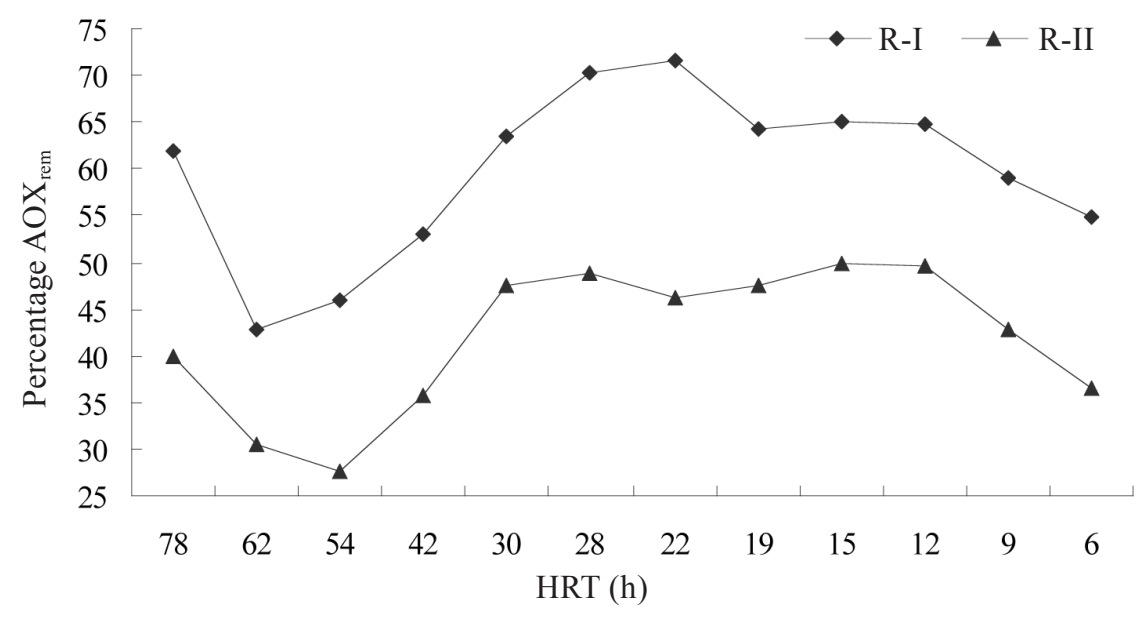

Figure 6. Effects of HRT on AOX removal.

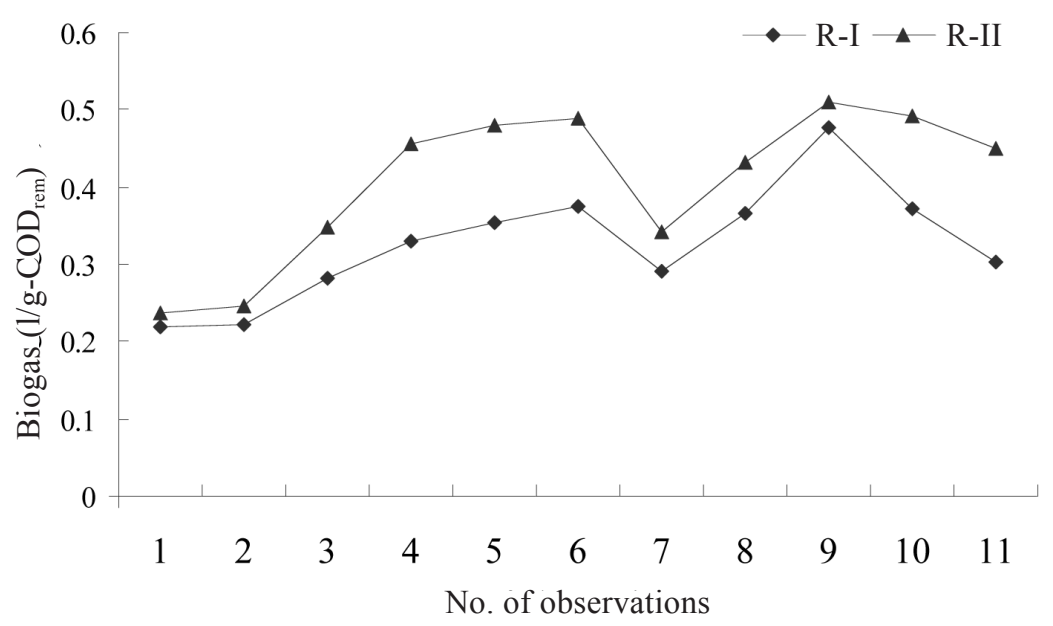

Figure 7. Amount of biogas production. 
reactors R-I and R-II in the last weeks of the study period when the HRT was relatively low (below $12 \mathrm{~h}$ ). The reason is that the lower HRT promotes the washout of sludge from the reactor and hence the amount of biogas production decreases by design.

Under optimum conditions, the average amount of biogas produced in the reactors R-I and R-II was observed to be $0.33 \mathrm{l} / \mathrm{g} \mathrm{COD}_{\text {removed }}$ and $0.41 \mathrm{l} / \mathrm{g} \mathrm{COD}_{\text {removed, }}$ respectively. The average methane composition was slightly different for both the reactors R-I and R-II, i.e. $61 \%$ and $58 \%$, respectively. The enhancement in the methane composition was mainly due to the adsorption of refractory material by activated carbon. It was also noticed that the reactor R-I displayed a reduced amount of biogas generation, which might be due to the low mixing of substrate and biomass owing to the presence of activated carbon within the system that made the sludge particles more dense. The overall gas production in both the reactors remained close to the theoretical value of $0.35 \mathrm{l} / \mathrm{g} \mathrm{COD}$ removed which indicated the efficacy and consistency of the systems used in the study, as it has been previously reported that the presence of recalcitrant material within such kinds of waste caused reduction in biogas production (Arshad et al. 2009). Comparison between biogas productions under anaerobic condition for similar waste is also mentioned in Table 2.

\section{Bio-kinetic Co-efficient}

Puspendu (2008) reported that the Garu secondorder model was the best fit model for a wide range of data sets in the UASB reactor. For this study, the kinetic constants of $\mathrm{Y}, \mathrm{k}_{\mathrm{d}}, \mathrm{k}, \mathrm{K}_{\mathrm{s}}$ were determined by using the experimental data obtained during the course of study period to explore the performance appraisal of reactor R-I. The intercept line and the slope of line from the graph plotted between $\mathrm{Lr}$ and $1 / \theta_{\mathrm{c}}$ gave the values of $k_{d}$ and $Y$, respectively. This plot is shown in Figure 8. Y was determined to be 0.26 g-VSS/g-TOC or $0.8 \mathrm{~g}$-VSS/g-COD, while $\mathrm{k}_{\mathrm{d}}$ was found to be $0.02 \mathrm{~d}^{-1}$. The plot between $1 / \mathrm{S}$ and $1 / \mathrm{Lr}$ is shown in Figure 9. As shown, $\mathrm{k}$ and Ks were determined to be $0.7 \mathrm{~g}$-TOC/g-VSS.d (about 1.9 g-COD/g-VSS.d) and $0.3 \mathrm{~g}$-TOC/1, respectively.

The kinetic constants determined in this study were compared with similar work conducted by using only methanol, as the sole carbon source in the feeding solution, as shown in the Table 3. This table indicates that the presence of the use of actual paper mill effluent has negligible impact on the bio-kinetic constant of the reactors. The ' $\mathrm{k}$ ' value appears to be

Table 2. Comparison of similar studies.

\begin{tabular}{|c|c|c|c|c|}
\hline Substrate & Operational parameters & $\begin{array}{l}\text { COD and AOX } \\
\text { removal }\end{array}$ & Biogas production & Reference \\
\hline Methanol & $\mathrm{OLR}=21 \mathrm{~g}-\mathrm{COD} / \mathrm{L}-\mathrm{d}$ & $\mathrm{COD}=70 \%$ & $0.30 \mathrm{l} / \mathrm{g}-\mathrm{COD}_{\text {removed }}$ & Bhatti 1996 \\
\hline $\begin{array}{l}\text { Synthetic waste } \\
\text { (Chlorophenol) }\end{array}$ & $\begin{array}{l}\mathrm{OLR}=6.25 \mathrm{~g}-\mathrm{TOC} / \mathrm{L} \cdot \mathrm{d} \\
\mathrm{HRT}=12-48 \mathrm{~h}\end{array}$ & $\mathrm{COD}=80 \%$ & $\begin{array}{l}0.131 / \mathrm{g}-\mathrm{COD}_{\text {removed }} \\
\mathrm{CH}_{4}=60 \%\end{array}$ & $\begin{array}{l}\text { Arshad \& } \\
\text { Hashim } 2008\end{array}$ \\
\hline $\begin{array}{l}\text { NSSC pulping } \\
\text { effluent }\end{array}$ & $\begin{array}{l}\mathrm{OLR}=2.75 \mathrm{~kg}-\mathrm{COD} / \mathrm{m}^{3} \mathrm{~d} \\
\mathrm{HRT}=38 \mathrm{~h}\end{array}$ & $\mathrm{COD}=35 \%$ & $\begin{array}{l}0.17 \mathrm{~m}^{3} / \mathrm{kg}-\mathrm{COD}_{\text {rem }}-\mathrm{d} \\
\mathrm{CH}_{4}=61 \%\end{array}$ & $\begin{array}{l}\text { Arshad et al. } \\
2009\end{array}$ \\
\hline $\begin{array}{l}\text { Bleaching effluent } \\
\text { (Paper mill) }\end{array}$ & $\begin{array}{l}\mathrm{OLR}=2.14 \mathrm{~kg}-\mathrm{COD} / \mathrm{m}^{3}-\mathrm{d} \\
\mathrm{HRT}=38 \mathrm{~h}\end{array}$ & $\begin{array}{l}\mathrm{COD}=64 \% \\
\mathrm{AOX}=49 \%\end{array}$ & $\begin{array}{l}0.19 \mathrm{l} / \mathrm{g}-\mathrm{COD}_{\text {removed }} \\
\mathrm{CH}_{4}=58 \%-60 \%\end{array}$ & $\begin{array}{l}\text { Arshad \& } \\
\text { Hashim } 2010\end{array}$ \\
\hline $\begin{array}{l}\text { Paper mills } \\
\text { effluent }\end{array}$ & $\begin{array}{l}\mathrm{OLR}=3.5 \mathrm{~kg}-\mathrm{COD} / \mathrm{m}^{3}-\mathrm{d} \\
\mathrm{HRT}=22 \mathrm{~h}\end{array}$ & $\begin{array}{l}\mathrm{COD}=88 \% \\
\mathrm{AOX}=72 \%\end{array}$ & $\begin{array}{l}0.331 / \mathrm{g}-\mathrm{COD}_{\text {removed }} \\
\mathrm{CH}_{4}=60 \%-61 \%\end{array}$ & This study \\
\hline
\end{tabular}




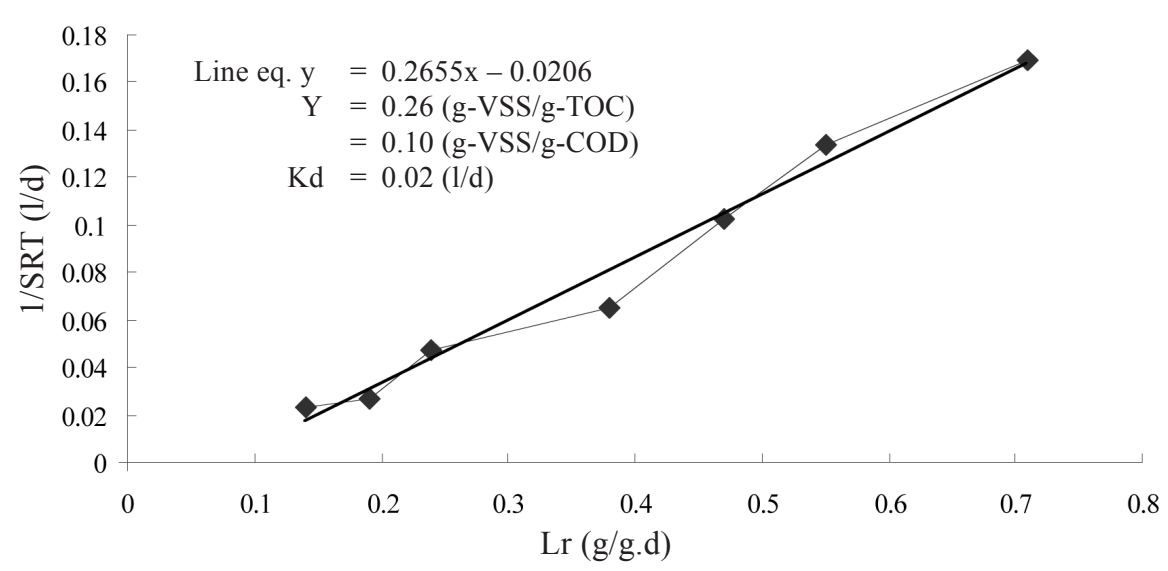

Figure 8. Relationship between specific subtrate removal rate and inverse of SRT.

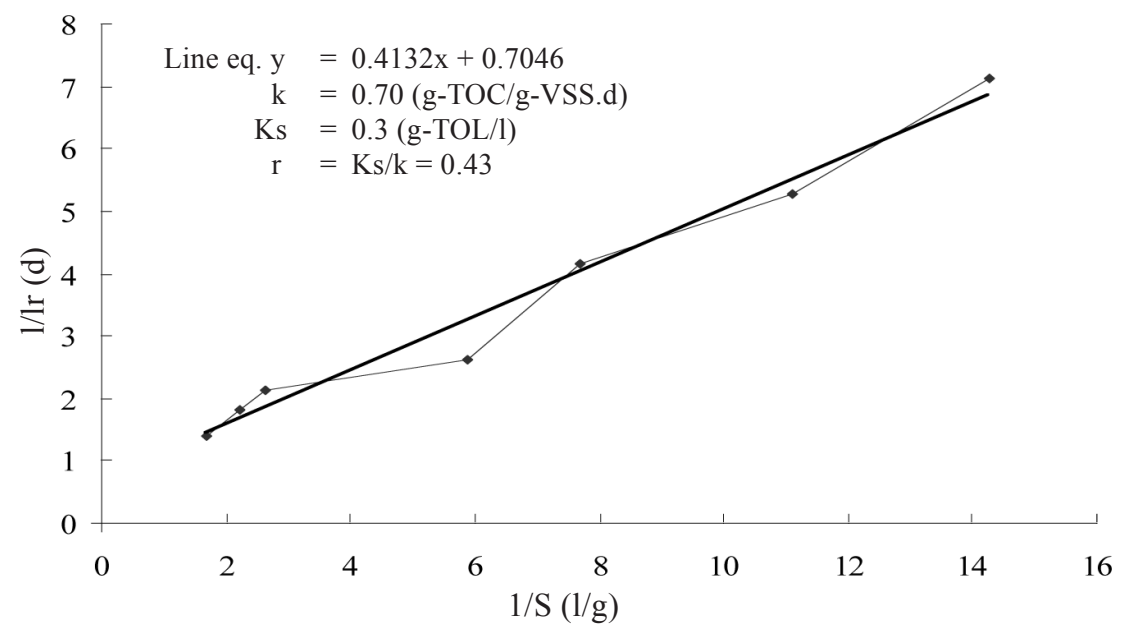

Figure 9. Determination of kinetic coefficiants of $k$ and $K s$.

reasonable, showing the good potential of the applicability of anaerobic treatment of paper mill effluent in the presence of activated carbon and methanol.

\section{CONCLUSION AND RECOMMENDATIONS}

The usage of methanol as an easily biodegradable substance in the presence of activated carbon with the digested sludge in a UASB reactor seems to be an extremely viable option for the treatment of paper mill effluent. The COD removal efficiency can be specifically enhanced from $64 \%$ to $88 \%$ and the AOX removal from $47 \%$ to $72 \%$, at an OLR of $3.5 \mathrm{~kg}-\mathrm{COD} / \mathrm{m}^{3}$ day. The optimum HRT for the UASB reactor design to treat such wastes under a mesophilic range of temperature and neutral $\mathrm{pH}$ was found to be $22 \mathrm{~h}$.

The presence of activated carbon in the UASB reactor reduced the mixing of biomass and substrate, and consequently affected the formation of biogas. The gas production could be decreased from $0.41 \mathrm{l} / \mathrm{g} \mathrm{COD}_{\text {rem }}$ to $0.33 \mathrm{l} / \mathrm{g}$ $\mathrm{COD}_{\text {rem }}$ by using activated carbon within the 
Table 3. Comparison of kinetic constants.

\begin{tabular}{l|ccccc}
\hline \multicolumn{1}{c|}{ Type of waste } & $\begin{array}{c}\mathrm{Y} \\
(\mathrm{g}-\mathrm{VSS} / \mathrm{g}-\mathrm{TOC})\end{array}$ & $\begin{array}{c}\mathrm{K}_{\mathrm{d}} \\
\left(\mathrm{day}^{-1}\right)\end{array}$ & $\begin{array}{c}\mathrm{Ks} \\
(\mathrm{g}-\mathrm{TOC} / \mathrm{L})\end{array}$ & $\begin{array}{c}\mathrm{k} \\
(\mathrm{g}-\mathrm{TOC} / \mathrm{g} \text {-VSS.d) }\end{array}$ & Reference \\
\hline Methanol & 0.213 & 0.005 & 0.385 & 1.11 & Bhatti et al. 1996 \\
Paper mill effluent & 0.26 & 0.02 & 0.30 & 0.70 & This study \\
\hline
\end{tabular}

reactor. The average methane composition of biogas showed an increase from $58 \%$ to $61 \%$ by using activated carbon and methanol within the UASB reactor. Kinetic coefficients of $\mathrm{k}, \mathrm{K}_{\mathrm{s}}$, $\mathrm{Y}$ and $\mathrm{k}_{\mathrm{d}}$ for paper mills effluent treatment in UASB reactors were $0.7 \mathrm{~g}$-TOC/g-VSS.d, 0.3 g-TOC/1, $0.26 \mathrm{~g}-\mathrm{VSS} / \mathrm{g}-\mathrm{TOC}$ and $0.02 \mathrm{day}^{-1}$, respectively.

The feasibility of the treatment for paper mill effluent in a single-step UASB reactor in the presence of methanol, as an easily biodegradable substance, and activated carbon is a highly viable method but detailed study is essential to identify the exact behavior of the activated carbon and methanol during the process of digestion. Cost analysis for design of the UASB reactor needs to be evaluated on a mega scale if activated carbon is to be used, while the impact of variable $\mathrm{pH}$ and temperature also needs to be evaluated thoroughly.

Date of submission: June 2011 Date of acceptance: September 2011

\section{REFERENCES}

Ali, M \& Sreekrishnan, TR 2001, 'Aquatic toxicity from pulp and paper mill effluents: a review', $A d v$. Environ. Res., vol. 5, pp. 175-196.

Arshad, A \& Hashim, NH 2008, 'Feasibility of co-treatment of chlorophenol with methanolic wastes, using UASB reactor', in Proceedings of 1st International Conference on Role of Chemistry for Environmental Preservation, Lahore, Pakistan.

Arshad, A, Hashim, NH, Inthikhab AQ \& Athar, S 2009, 'Treatment feasibility of NSSC pulping effluent using UASB reactor', Journal of Water, Energy and Environment, vol. 5, pp. 57-60.
Arshad, A \& Hashim, NH 2010, 'Treatment feasibility of the bleaching effluent obtained from NSSC pulp and paper mill in a UASB reactor', Journal of Engineering and Applied Sciences, vol. 29 , no. 3, pp. $43-31$.

Arshad, A, Hashim, NH, Inthikhab, A 2010, 'Effects of methanol on the treatability of black liquor using UASB reactor', Journal of Water, Energy and Environment, vol. 6, pp. 42-46.

Arshad, A, Intikhab, AQ, Tauseef, J \& Hashim, NH 2010, 'Pilot plant investigation on the start-up of a UASB reactor using sugar mill effluent', ASEAN Journal on Science and Technology for Development, vol. 27, no. 1.

Athar, H, Pradeep K \& Indu, M 2008, 'Treatment of phenolic wastewater in UASB reactor: effects of nitrogen and phosphorous', Bioresource Technology, vol. 99, No. 17, pp. 8497-8503.

Anushuya, R \& Gupta, SK 2008, 'Effect of hydraulic retention time on the biodegradation of complex phenolic mixture from stimulated coal wastewater in hybrid UASB reactors', Journal of Hazardous Material, vol. 153, no. 1-2, pp. 843-851.

AWWA and WEF 2005, Standard methods for the examination of water and wastewater, APHA Publication, Washington DC.

Bajaj, M, Gallert, C \& Winter, J. 2009, 'Treatment of phenolic wastewater in anaerobic fixed bed reactor (AFBR) - Recovery after shock loading' Journal of Hazarodus Materials, vol. 162, no. 2-3, pp. 1330-1339.

Bajpai 2000, 'Microbial degradation of pollutants in pulp mill effluent', Adv. Appl. Microbiol, vol. 48, pp. 9-134.

Bhatti, ZI, Furukawa, K \& Fujita, M 1996, 'Feasibility of methanolic wastes treatment in UASB rectors', Water Research, vol. 30, pp. 2559-2568.

Buhr, HO \& Andrews, JF 1977, 'The thermophillic anaerobic digestion process', Water Research, vol. 11, pp. 129-143. 
Environmental Draft Report, Pak-EPA 1999, Environmental Technology Programme for Industries, Federal Press, Islamabad.

Ferguson, JF \& Dalentoft, E 1991, 'Investigation of anaerobic removal and degradation of organic chlorine from Kraft bleaching wastewater', Water Sci. Technol., vol. 24, pp. 241-250.

Fitzsimons, R, Ek, M \& Eriksson, KEL 1990, 'Anaerobic dechlorination/degradation of chlorinated organic compounds of different molecular masses in bleach plant effluent', Environ. Sci. Technol., vol. 29, pp. 1744-1748.

Francis, DW, Turner, PA \& Wearing, JT 1997, ‘AOX reductions of Kraft bleach plant effluent by chemical pre-treatment, pilot-scale trials', Water Res., vol. 31, no. 10, pp. 2397-2404.

Grin, P, Roersma, R \& Lettinga, G 1985, 'Anaerobic treatment of raw domestic sewage in UASB reactors at temperature from $9^{\circ} \mathrm{C}-20^{\circ} \mathrm{C}^{\prime}$, in Proc. Seminar/Workshop on Anaerobic Treatment of Sewage, University of Massachusetts, Amherst, Massachusetts.

Hall, ER, Onysko, KA \& Parker, WJ 1995, 'Enhancement of bleach kraft organochloride removal by coupling membrane filtration and anaerobic treatment', Environ. Technol., vol. 16, pp. 115-126.

Henze, M \& Harremoes, P 1983, 'Anaerobic treatment of wastewater in fixed film reactor - a literature review', Water Sci. Technol., vol. 15, pp. 94-101.

Hiroshi, T \& Masasumi, K 2009, 'Development of an expanded-bed GAC reactor for anaerobic treatment of terephthalate-containing wastewater', Water Research, vol. 43, no. 2, pp. 417-422.

Kannady, KJ \& Van den Berg 1982, 'Stability and performance of anaerobic fixed film reactors during hydraulic overloading at $10^{\circ} \mathrm{C}-35^{\circ} \mathrm{C}$, Water Research, vol. 16, pp. 1391-1398.

Lee, EGH, Crowe, MF \& Stutz, H 1993, 'Pilot study of sequential anaerobic/aerobic biological process for dechlorination of whole mill Kraft effluent', in CPPA Ann. meeting Montreal, Canada.

Lettinga, G, Pol, LWH, Weigant, WM, Dezeeuw, WJ, Rinzema, A, Grin, PC, Roersma, RE \& Homba, SW 1984, 'High rate anaerobic wastewater treatment using the UASB reactor under a wide range of temperature conditions', $J$. of Fermentation of Bioeng., vol. 70, no. 2, pp. 119127.

Lettinga, G, Velsen, LV, Zeeuw, WD, Hobma, SW \& Klapwijk A 1980, 'Use of UASB reactor for biological wastewater treatment, especially for anaerobic treatment', Biotechnology and Bioengineering, vol. 22, pp. 699-734.

Mahadevaswamy, BM, Sadashiva, M \& Girijamma, AR 2004, 'Performance evaluation of UASB reactor for treatment of paper mill wastewater', $J$ Environmental Sciences, vol. 16, no. 2, pp. 194-198.

Mtethiwa, AH, Munyenyembe, A, Jere, W \& Nyali, E 2008, 'Efficiency of oxidation ponds in wastewater treatment', International Journal of Environmental Research, vol. 2, no. 2, pp. 27-31.

Puspendu, B \& Ghangrekar, MM 2008, 'Analysis, evaluation and optimization of kinetic parameters for performance appraisal and design of UASB reactors', Bioresource Technology, vol. 99, no. 7, pp. 2132-2140.

Rajakumar \& Meenambul 2008, 'Comparative study on start-up performance of HUASB and AF reactors treating poultry slaughterhouse wastewater', International Journal of Environmental Research, vol. 2, no. 4, pp. 18-25.

Savant, DV, Abdul-Rahman, R \& Ranadi, DR 2005, 'Anaerobic digestion of absorbable organic halides (AOX) from pulp and paper industry wastewater', Bioresource Technology, vol. 30, pp. $30-40$.

Schellinkhout, A 1993, 'UASB technology for sewage treatment: experience with a full scale plant and its applicability in Egypt', Water Sci. Technol., vol. 27, no. 9, pp. 173-180.

Scholz-Muramatsu, H, Neumann, A, MeBmer, M, Moore, E \& Diekert, G 1995, 'Isolation and characterization of Dehalospirillum mutivorans gen. non.sp.nov, a tetrachloroethene utilizing, strictly anaerobic bacterium', Arch. Microbiol., vol. 163, pp. 48-56.

Switzenbaum, MS \& Jewell, W 1980, 'Anaerobic attached-film expanded-bed reactor treatment', Journal Water Poll. Control Fed., vol. 52, pp. 1953-1965. 
Tezel, U, Guven, E, Erguder, TH \& Demirer, GN 2001, 'Sequential (anaerobic/aerobic) biological treatment of Dalaman, SEKA pulp and paper industry effluent', Waste Management, vol. 21, pp. 717-724.

Wijetunga, S, Xiu-Fen, L, Wen-Quan, R \& Chen, J 2008, 'Evaluation of the efficacy of UASB reactor in removal of color and reduction of COD in real textile wastewater', Bioresource Technology, vol. 99, no. 9, pp. 3692-3699.

Yoochatchaval, WI, Ohashi, A, Harada, H, Yamaguchi, TI \& Syutsubo, K 2008, 'Characteristics of granular sludge in an EGSB reactor for treating low strength wastewater', International Journal of Environmental Research, vol. 2, no. 4, pp. $16-21$. 